\title{
In memoriam: Dr. Seng-jaw Soong (1943-2012): Annals of Surgical Oncology Statistician and Statistician Extraordinaire
}

\author{
Charles M. Balch, MD FACS \\ Department of Surgery, University of Texas Southwestern Medical Center, Dallas, TX
}

Seng-jaw Soong was a member of the Annals of Surgical Oncology Editorial Board (as its statistician), Chair of the Biostatistics Committee for the American Joint Committee on Cancer (AJCC), Vice-Chair of the Melanoma Committee for more than a decade, and Professor Emeritus of Biostatistics at the University of Alabama at Birmingham (Fig. 1). Dr. Soong was indeed a statistician extraordinaire who had a pivotal role in shaping our understanding of melanoma prognosis and staging, as well as being the group statistician for many seminal studies of antiviral therapies. Moreover, he was a mathematical genius, having been one of the first to publish a cancer clinical analysis using the Cox logistic regression analysis as well as other mathematical predictive models that are used by clinicians and researchers worldwide.

Seng-jaw was a visionary leader who left a legacy as a clinical statistician that few can match, and whose impact will benefit cancer patients for generations. And at a personal level, we admired him as an authentic and caring person whom we all loved and respected.

Dr. Soong brought a unique statistical dimension to clinical research that revolutionized entire fields of medicine, not only in the areas of melanoma, head and neck cancer, and gynecologic cancers, but also in seminal studies that led directly to FDA approval of new drugs for life-threatening viral infections.

His research legacy is virtually unmatched among clinical statisticians. Indeed, many will emulate what he has accomplished over a career, but few will duplicate his impressive scholarly record. Seng-jaw was an author of more than 300 scientific publications plus many book chapters and textbooks. But this prodigious number of

(C) Society of Surgical Oncology 2013

Published Online: 16 May 2013

C. M. Balch, MD FACS

e-mail: charles.balch@UTsouthwestern.edu publications only reflects part of his scientific productivity. Another important benchmark reflecting the impact and value of published work is measured by how many times colleagues cite one's articles in their own publications. Using this parameter, Seng-jaw's 300 scientific publications were quoted in the literature more than 1,000 times during each one of the past four years, or a total of 18,600 times over 30 years, an average of 63 citations for each of his articles.

His impact in the melanoma and virology fields is also evident in his ten most cited articles (see Table 1). Two of these with Dr. Richard Whitley were cited 622 and 385 times, respectively. Six of the remaining eight were melanoma papers cited 300 to 500 times each. His top two cited papers, published in 2001, reflected the revolutionary changes he brought to the staging and prognosis of melanoma. These two papers have been cited 1,075 and 1,436 times, respectively. Also, for 30 years, Dr. Soong played an instrumental role in melanoma education through his coediting the seminal textbook Cutaneous Melanoma, currently in its 5 th edition.

In addition to celebrating the remarkable professional achievements of Seng-jaw Soong, his colleagues admired him for his authentic character, his genuine, sensitive, and humble personality, his commitment as a mentor and teacher, and his devotion as a husband and father.

Some memorable comments that reflect how others defined his legacy:

From Dr. David Byrd at the University of Washington, Vice-Chair of the AJCC:

I also had the pleasure to work with him for many years through AJCC activities and others. I agree completely with your comments about his authenticity and humbleness. I would add that he also embodied the highest integrity, remarkably high standard setting for fidelity in interpretation of data, 


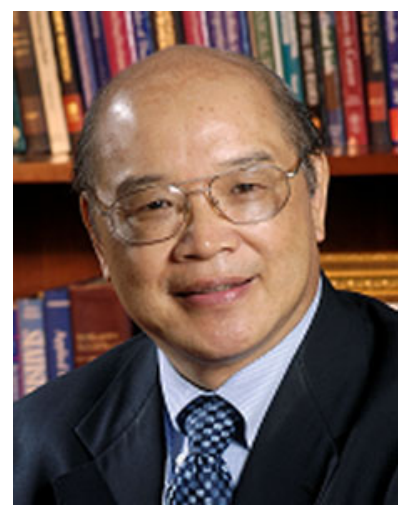

FIG. 1 Dr. Seng-jaw Soong

and a commitment to full collegiality with his partners in cancer.

From Dr. Stephen Edge at Roswell Park CC in Buffalo, the past-Chair of the AJCC:

Seng-jaw made such enormous contributions over the years to the cause of improving patient care and outcomes. His work in understanding melanoma in particular has benefited untold numbers of people around the world. His influence and impact will continue in our field for decades to come.

From Dr. Jeffrey Gershenwald at the University of Texas MD Anderson in Houston and the Vice-Chair of the AJCC Melanoma Committee and member of its Executive Committee:

Seng-jaw was an incredibly talented, team-oriented, and genuinely gentle human being in every dimension. His interest and mastery of the clinical problem of melanoma over the past few decades-with paradigm-shifting achievement in staging and prognosis - has helped us all as we strive to conquer this challenging problem and better serve our patients worldwide. His legacy as a statistician who became entrenched in the clinical aspects of the disease process has served and will continue to serve as a model for all statisticians and bioinformaticians alike. We will all miss him dearly.

From Dr. John Thompson, Director of the Melanoma Institute of Australia in Sydney:

Seng-jaw leaves a remarkable legacy and will long be remembered as a humble but hugely talented biostatistician who made remarkable contributions to melanoma research.

From Dr. Michael Atkins, Deputy Director of the Georgetown University Cancer Center:

He was such a force for good. His work has had tremendous impact on our understanding of melanoma prognosis. He surely will be missed, both professionally and personally.

From Dr. DuPont Guerry, Emeritus Professor of Medicine at the University of Pennsylvania:

He was one of those who led us out of the darkness of anecdotal medicine.

From Dr. Richard Whitley, Professor of Pediatric Infectious Diseases at the University of Alabama at Birmingham:

Seng-jaw taught all of us how to apply statistics to biologic problems. He was the first person to apply Kaplan-Meier survival plots to an infectious diseases problem. Indeed, he paved the way for the success of my career and the careers of many of my colleagues. He was a teacher for all of us. For over thirty years, he helped guide the NIH Antiviral Study Group. With his adroitness at managing and interpreting our data bases, we changed the standard of care for at least six diseases, leading to new drug licensures.

TABLE 1 Ten most-cited articles by Dr. Seng-jaw Soong

\begin{tabular}{|c|c|}
\hline Title & $\begin{array}{l}\text { Final version of the American Joint Committee on Cancer staging system } \\
\text { for cutaneous melanoma }\end{array}$ \\
\hline Author(s) & Balch CM, Buzaid AC, Soong SJ, et al. \\
\hline Source & $\begin{array}{l}\text { Journal of Clinical Oncology Volume: } 19 \text { Issue: } 16 \text { Pages: 3635-3648 } \\
\text { Published: Aug } 152001\end{array}$ \\
\hline Times cited & 1,436 \\
\hline Title & $\begin{array}{l}\text { Prognostic factors analysis of } 17,600 \text { melanoma patients: Validation of } \\
\text { the American Joint Committee on Cancer melanoma staging system }\end{array}$ \\
\hline Author(s) & Balch CM, Soong SJ, Gershenwald JE, et al. \\
\hline Source & $\begin{array}{l}\text { Journal of Clinical Oncology Volume: } 19 \text { Issue: } 16 \text { Pages: 3622-3634 } \\
\text { Published: Aug } 152001\end{array}$ \\
\hline Times cited & 1,075 \\
\hline
\end{tabular}


TABLE 1 continued

\section{Title}

Author(s)

Source

Times cited

Title

Author(s)

Source

Times cited

Title

Author(s)

Source

Times cited

Title

Author(s)

Source

Times cited

Title

Author(s)

Conference

Source

Times cited

Title

Author(s)

Source

Times cited

Title

Author(s)

Source

Times cited

Title

Author(s)

Source

Times cited
Adenine-arabinoside therapy of biopsy-proved herpes-simplex encephalitis Whitley RJ, Soong SJ, Dolin R, et al.

New England Journal of Medicine Volume: 297 Issue: 6 Pages: 289-294 DOI: 10.1056/NEJM197708112970601 Published: 1977

\section{2}

Final Version of 2009 AJCC Melanoma Staging and Classification

Balch CM, Gershenwald JE, Soong, SJ, et al.

Journal of Clinical Oncology, Volume: 27, Issue: 36, Pages: 6199-6206. DOI: 10.1200/JCO.2009.23.4799 Published: Dec 20, 2009

\section{7}

Vidarabine versus acyclovir therapy in herpes-simplex encephalitis Whitley RJ, Alford CA, Hirsch MS, et al.

New England Journal of Medicine Volume: 314 Issue: 3 Pages: 144-149 DOI: 10.1056/NEJM198601163140303 Published: Jan 16, 1986

470

Multifactorial analysis of melanoma-prognostic histopathological features comparing Clark's and Breslow's staging

Balch CM, Murad TM, Soong SJ, et al.

Annals of Surgery Volume: 188 Issue: 6 Pages: 732-742

DOI: 10.1097/00000658-197812000-00004 Published: 1978

431

Efficacy of an elective regional lymph node dissection of 1 to $4 \mathrm{~mm} \mathrm{t}$ hick melanomas for patients 60 years of age and younger

Balch CM, Soong SJ, Bartolucci AA, et al.

116th Annual Scientific Session of the American Surgical Association Location: Phoenix, AZ. Date: Apr 18-20, 1996 Sponsor(s): American Surgical Association

Annals of Surgery Volume: 224 Issue: 3 Pages: 255-263

DOI: 10.1097/00000658-199609000-00002. Published: Sept 1996

401

Relationship between dihydropyrimidine dehydrogenase-activity and plasma 5-fluorouracil levels with evidence for circadian variation of enzyme activity and plasma drug levels in cancer patients receiving 5-fluorouracil by protracted continuous infusion

Harris BE, Song R, Soong SJ, et al.

Cancer Research Volume: 50 Issue: 1 Pages: 197-201 Published: Jan 1, 1990

385

A comparison of prognostic factors and surgical results in 1,786 patients with localized (stage 1) melanoma treated in Alabama, USA, and New South Wales, Australia

Balch CM, Soong SJ, Milton GW, et al.

Annals of Surgery Volume: 196 Issue: 6 Pages: 677-684

DOI: 10.1097/00000658-198212001-00011 Published: 1982

314

A multifactorial analysis of melanoma: III. Prognostic factors in melanoma patients with lymph node metastases (stage II) Balch CM, Soong SJ, Murad TM, et al.

Annals of Surgery Volume: 193 Issue: 3 Pages: 377-388

DOI: 10.1097/00000658-198103000-00023 Published: 1981

301 
Yes, Seng-jaw Soong left a legacy as a clinical biostatistician and in his innovative use of mathematical modeling that developed predictive tools and outcomes studies used worldwide. He had the intellectual skills to understand the biology and natural history of the diseases he was analyzing. His prowess as a clinical statistician has benefited many patients, and his research has contributed to our fund of knowledge that we use every day around the world. 